\title{
Aspekty polityki Unii Europejskiej wobec Afryki w kontekście kryzysu migracyjnego
}

\section{Uwagi wstępne}

Celem niniejszej pracy jest analiza polityki Unii Europejskiej wobec Afryki w kontekście kryzysu migracyjnego w latach 2011-2017. Współpraca z państwami afrykańskimi odegrała kluczową rolę podczas kryzysu migracyjnego w Unii Europejskiej. Analiza jakościowa źródeł pierwotnych w postaci aktów prawnych i dokumentów typu soft law Unii Europejskiej skłoniła autora do postawienia następującej hipotezy badawczej: Po wybuchu kryzysu migracyjnego Unia Europejska dokonała rewizji swojej polityki wobec Afryki. Ponadto UE zintensyfikowała działania zewnętrzne wobec tych państw afrykańskich, które są krajami pochodzenia lub krajami tranzytowymi.

Jeszcze do niedawna najważniejszymi zagadnieniami współpracy pomiędzy Unią Europejską a Afryką był zrównoważony rozwój oraz współpraca gospodarcza. Rosnąca liczba migrantów napływających z południa od 2011 r., a przede wszystkim exodus z 2015 r. z państw afrykańskich i azjatyckich sprawił, że temat migracji pojawia się znacznie częściej we wzajemnych porozumieniach i deklaracjach.

Większość opracowań zajmujących się polityką Unii Europejskiej wobec Afryki skupia się na relacjach pomiędzy UE a państwami Afryki, Karaibów i Pacyfiku (AKP), co wynika z tradycji historycznej i szczególnego traktowania tych krajów w polityce zewnętrznej Unii Europejskiej. W niniejszej pracy podjęto próbę przedstawienia ogólnej koncepcji polityki Unii Europejskiej wobec Afryki przy zastosowaniu metody indukcyjnej. Próbę przeglądu polityki Unii Europejskiej wobec Afryki w kontekście kryzysu migracyjnego podejmowano jak dotąd m.in. w badaniach Amandy Bisong, w których autorka dokonała analizy współpracy transregionalnej w zakresie migracji pomiędzy Unią Europejską a Wspólnotą Gospodarczą Państw Afryki Zachodniej (ECOWAS) wykorzystując teorię zarządzania wielopoziomowego (Bisong, 2018, s. 1).

Warto podkreślić, że dotychczasowa współpraca pomiędzy UE a państwami afrykańskimi po wybuchu kryzysu migracyjnego opierała się przede wszystkim na deklaracjach, inicjatywach i programach o charakterze prawnie niewiążącym, które dotyczyły poszczególnych regionów lub były adresowane ogólnie do całego kontynentu afrykańskiego. Taka strategia z jednej strony wpisywała się w idealistyczną wizję promowania integracji regionalnej. $Z$ drugiej zaś strony miała zastosowanie praktyczne, gdyż zaplanowanie działań dla regionu obejmującego kilka lub kilkanaście państw jest prostsze niż negocjowanie umów bilateralnych z poszczególnymi państwami (Frankowski, 2011, s. 12). Nie oznacza to jednak, że podejście bilateralne w ogóle nie było wykorzystywane. Potrzebę jego zastosowania zauważono jednak nieco później. 
Pierwsza część pracy została poświęcona podstawom prawnym polityki zewnętrznej Unii Europejskiej wobec Afryki. W części drugiej opisano przebieg intensyfikacji migracji z krajów afrykańskich, począwszy od 2011 r. Następnie przeanalizowano odpowiedź Unii Europejskiej na kryzys migracyjny w postaci europejskiego programu w zakresie migracji, postanowień podjętych na szczycie w Valletcie, zmian w globalnej strategii na rzecz polityki zagranicznej i bezpieczeństwa Unii Europejskiej. Ostatnia część pracy poświęcona została rozwojowi współpracy regionalnej i bilateralnej między UE a państwami afrykańskimi w dobie kryzysu migracyjnego.

\section{Ramy polityki Unii Europejskiej wobec Afryki}

Podstawę traktatową dla działań zewnętrznych Unii Europejskiej stanowi Część V Traktatu o funkcjonowaniu Unii Europejskiej (Traktat o funkcjonowaniu, s. 93-102) oraz Tytuł V Traktatu o Unii Europejskiej (Traktat o Unii, s. 16-29). Obejmują one szereg działań takich jak: Wspólna Polityka Handlowa, współpraca gospodarcza, finansowa i techniczna z państwami trzecimi, pomoc humanitarna, umowy międzynarodowe, Wspólna Polityka Zagraniczna i Bezpieczeństwa, w tym Wspólna Polityka Bezpieczeństwa i Obrony. Szczególną rolę przypisano Europejskiej Polityce Sąsiedztwa, którą umieszczono osobno w artykule ósmym Traktatu o Unii Europejskiej. Można więc zaryzykować stwierdzenie, że zewnętrzna polityka migracyjna UE opiera się zarówno na instrumentach prawnych, jak i instrumentach politycznych (Barcz, Kawecka-Wyrzkowska, Michałowska-Gorywoda, 2012, s. 129-130).

Najważniejszym instrumentem oddziaływania Unii Europejskiej na państwa Afryki Północnej jest Europejska Polityka Sąsiedztwa (EPS). W 2015 r. dokonano jej przeglądu, w wyniku którego migracja i mobilność stanowią jeden z głównych obszarów współpracy. Następstwem przeglądu EPS było także zwiększenie wydatków na kwestie związane z migracją (Nitszke, 2016, s. 388-392).

Obecnie nadrzędne ramy współpracy Unii Europejskiej z państwami Afryki Subsaharyjskiej zawarte są w umowie z Kotonu, w której znajdują się również postanowienia dotyczące współpracy pomiędzy Unią Europejską a Karaibami i państwami Pacyfiku. Została ona przyjęta w 2000 r. i zastąpiła konwencję z Lome z 1975 r. Kwestie dotyczące migracji uregulowane są w artykule 13, który przewidywał dialog pomiędzy państwami AKP a UE, podkreślał także przestrzeganie przez strony praw człowieka (Umowa, s. 10-11). Warto jednak zaznaczyć, że obecna umowa wygasa w lutym 2020 r. W związku z tym w sierpniu 2018 r. winny się rozpocząć negocjacje nowej umowy. W dniu 22 czerwca 2018 r. Rada Unii Europejskiej przyjęła już mandat negocjacyjny w tej sprawie. Na podstawie przyjętych wytycznych negocjacyjnych można założyć, że w przyszłej umowie więcej uwagi zostanie poświęcone problemowi migracji i mobilności (Council of the European Union, 2018, s. 16).

Nadrzędne ramy zewnętrznej polityki migracyjnej i azylowej Unii Europejskiej stanowi globalne podejście do kwestii migracji i mobilności (GPMM), które zostało przedstawione w komunikacie Komisji Europejskiej z dnia 18 listopada 2011 r. (Komisja Europejska, 2011, s. 1). Zastąpiło ono globalne podejście do migracji przyjęte przez Radę Europejską w grudniu 2005 r. Nowe podejście powstało w wyniku rosnącej liczby 
napływających migrantów w wyniku tzw. arabskiej wiosny. GPMM miała się opierać przede wszystkim na dialogach w kwestiach migracji i mobilności, mających stanowić podstawowy proces, za pomocą którego polityka migracyjna UE jest transponowana do obszaru stosunków zewnętrznych. Globalne podejście do kwestii migracji i mobilności winno być wdrażane przez Komisję Europejską, Europejską Służbę Działań Zewnętrznych (ESDZ) oraz państwa członkowskie zgodnie z ich zakresem kompetencji. Według zaleceń Komisji, GPMM miało opierać się na czterech filarach: organizowaniu i ułatwianiu legalnej migracji i mobilności, zapobieganiu nielegalnej migracji i handlowi ludźmi, ochronie międzynarodowej i wzmacnianiu zewnętrznej polityki azylowej oraz optymalizacji wpływu migracji i mobilności na rozwój (Komisja Europejska, 2011, s. 2-6).

Kontynent afrykański został uwzględniony w priorytetach geograficznych GPMM. Komisja podkreśliła znaczenie polityki sąsiedztwa UE wobec południowych krajów regionu Morza Śródziemnego. Zwróciła również uwagę na kluczową rolę wspólnej strategii Afryka-UE oraz dialogu na linii UE-AKP. W ramach wsparcia integracji regionalnej Komisja zapowiedziała rozwój procesu z Rabatu oraz poparła utworzenie nowego procesu w Rogu Afryki. Planowano ponadto zacieśnienie współpracy operacyjnej w kwestiach migracji i mobilności z dużymi gospodarkami, do których w Afryce należą Nigeria oraz Republika Południowej Afryki. Jako podstawę współpracy w dziedzinie migracji z poszczególnymi państwami Komisja wskazała partnerstwo na rzecz mobilności (Komisja Europejska, 2011, s. 8-11). Partnerstwo występuje w formie niewiążącej umowy zawieranej przez zainteresowane państwa członkowskie z krajami trzecimi, której celem jest współpraca w zarządzaniu migracjami. Porozumienia te mają złożony charakter prawny, z racji tego, że niektóre ich elementy należą do kompetencji UE, a inne zaś wyłącznie do państw członkowskich (Morawska, 2017, s. 99-100).

Zgodnie z założeniami przedstawionymi przez Komisję GPMM powinno być ukierunkowane na migrantów (Komisja Europejska, 2011, s. 7). Zgodnie z tą ideą, to jednostka ma być podmiotem podejmowanych działań.

Analogiczne podejście do problemu można odnaleźć w dyrektywie Parlamentu Europejskiego i Rady w sprawie zapobiegania handlowi ludźmi i zwalczania tego procederu oraz ochrony ofiar z dnia 5 kwietnia 2011 r. (Dyrektywa, s. 1). Wprowadza ona standardy postępowania w przypadku ofiar handlu ludźmi oraz wytyczne odnośnie do walki z tym przestępstwem. Dyrektywa ma znaczenie dla polityki UE wobec Afryki, ponieważ to właśnie na tym kontynencie siatki przemytnicze występują na dużą skalę.

W reprezentowanym podejściu widać, że Unia Europejska traktowała dobre zarządzanie migracją jako szansę na rozwój gospodarczy, wzrost konkurencyjności i wzbogacenie społeczeństwa europejskiego. To zarządzanie miało się opierać na kontrolowanej i legalnej migracji, nie przewidywało jednak potrzeby zarządzania kryzysowego w obliczu intensywnego napływu migrantów w krótkim czasie. Późniejsza ewolucja podejścia Unii Europejskiej pokazuje osłabienie wspomnianego wyżej ukierunkowania na migrantów na rzecz zapewnienia bezpieczeństwa i lepszej ochrony granic zewnętrznych.

\section{Intensyfikacja migracji z Afryki}

Unia Europejska od zawsze stanowiła atrakcyjny cel dla migrantów z Afryki. Od początku 2011 r. presja na granice zewnętrzne UE uległa znacznemu zwiększeniu. 
Przyczyną tego stanu rzeczy była wojna domowa w Libii, która rozpoczęła się 15 lutego $2011 \mathrm{r}$. Podczas wojny strony zerwały włosko-libijski traktat o walce z nielegalną imigracją obowiązujący od $2008 \mathrm{r}$. W rezultacie w pierwszej połowie $2011 \mathrm{r}$. do Włoch przybyło ponad 40 tys. migrantów. $Z$ powodu przeludnienia wyspy Lampedusa lokalne władze zmuszone były do ogłoszenia stanu kryzysu humanitarnego. Rząd włoski zainicjował także utworzenie operacji „Hermes” mającej na celu monitorowanie południowej granicy Unii Europejskiej przez Europejską Agencję Zarządzania Współpracą Operacyjną na Zewnętrznych Granicach Państw Członkowskich Unii Europejskiej (Frontières extérieures - Frontex) (Węc, 2017, s. 8). W 2015 r. nastąpił punkt kulminacyjny kryzysu migracyjnego Unii Europejskiej. Liczba wniosków o azyl przekroczyła wówczas $1 \mathrm{mln} 322$ tys. (Eurostat, 2018, s. 1).

Jak widać na załączonym poniżej wykresie, w 2015 r. tzw. centralnym szlakiem śródziemnomorskim, wykorzystywanym przede wszystkim przez migrantów pochodzących z Afryki do Unii Europejskiej, przybyło około 153 tys. osób. Zaś zachodnim szlakiem śródziemnomorskim, który stanowił drugą najpopularniejszą drogę dla przybyszy z Afryki, dotarło zaledwie 16 tys. przesiedleńców. W porównaniu z liczbą sięgającą 860 tys. migrantów podążających wschodnim szlakiem śródziemnomorskim, wykorzystywanym przede wszystkim przez uciekinierów z państw azjatyckich z Syrią na czele, skala migracji z Afryki była znacznie mniejsza. W 2017 r. mamy do czynienia $\mathrm{z}$ załamaniem trendu zwyżkowego na centralnym szlaku śródziemnomorskim. Jednocześnie nieznacznie rośnie liczba migrantów wykorzystujących zachodni szlak śródziemnomorski.

\section{Wykres 1. Liczba prób nielegalnego przekroczenia granicy na głównych szlakach migracyjnych w latach 2010-2017}

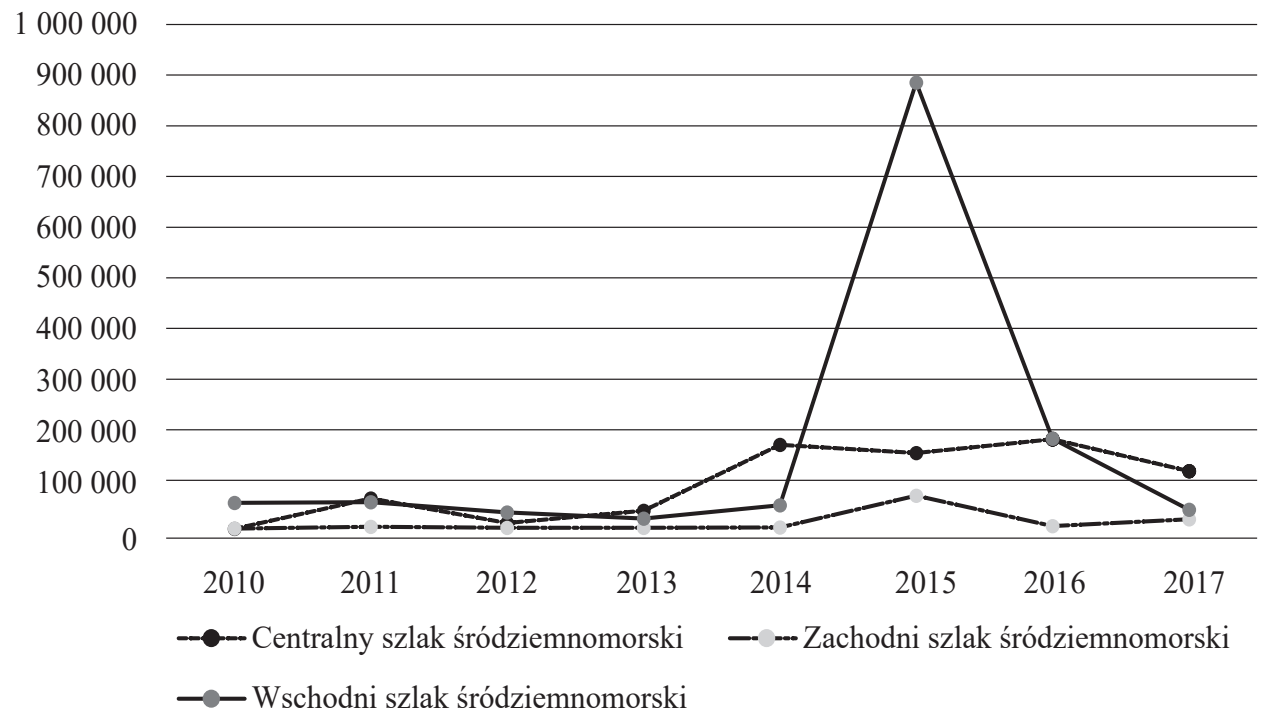

Źródło: Opracowanie własne na podstawie danych zebranych przez Europejską Agencję Straży Granicznej i Przybrzeżnej (Frontex), https://frontex.europa.eu/along-eu-borders/migratory-routes/western-mediterranean-route/. 


\section{Europejski program w zakresie migracji}

W komunikacie z maja 2015 r. Komisja Europejska przedstawiła Europejski program w zakresie migracji, który miał być szybką odpowiedzią na rosnącą presję migracyjną na zewnętrzne granice Unii Europejskiej (Komisja Europejska, 2015a, s. 1). Program zawierał różne działania, które UE winna podjąć w celu zbudowania zintegrowanego podejścia do problemu. UE zobowiązała się do potrojenia wydatków na wspólne operacje „Tryton” i „Posejdon”, mających na celu ratowanie życia migrantów na morzu. W reakcji na kryzys migracyjny Komisja Europejska zwróciła uwagę na fakt, że należy podjąć działania przeciwko siatkom przemytniczym z wykorzystaniem instrumentów funkcjonujących w ramach wspólnej polityki bezpieczeństwa i obrony. Europejski urząd policji (Europol) miał wzmocnić wspólny zespół operacyjny MARE w celu utworzenia pojedynczego punktu kontaktowego w zakresie walki z przemytem ludzi dla różnych agencji UE. Na skutek kryzysu migracyjnego w ramach programu zaproponowano utworzenie systemu relokacji uchodźców obejmującego 20 tys. miejsc w skali unijnej, który jak się później okazało nie został skutecznie wdrożony (Komisja Europejska, 2015a, s. 2-5).

Program zakładał także współpracę z państwami trzecimi w celu opanowania migracji zarówno w państwach pochodzenia, jak i tranzytu. W tym celu UE winna rozwinąć regionalne programy rozwoju, przede wszystkim w Afryce Północnej i Rogu Afryki. Zgodnie z programem do końca 2015 roku w Nigrze miało powstać wielofunkcyjne centrum pilotażowe, którego funkcją było zapewnienie osobom potrzebującym informacji, lokalnego wsparcia, a także możliwości przesiedlenia w bezpieczne miejsce lub powrotu do kraju pochodzenia. Zapewnienie informacji oznaczało w tym wypadku odwiedzenie od pomysłu dalszej i niebezpiecznej podróży przez Morze Śródziemne. Planowane centrum miało zostać utworzone we współpracy z Międzynarodową Organizacją ds. Migracji (IOM), Wysokim Komisarzem ONZ ds. Uchodźców i władzami Nigru (Komisja Europejska, 2015a, s. 6-9).

Dodatkowo w ramach WPBiO istniejące misje w Nigrze i Mali miały zostać wzmocnione w zakresie zarządzania granicami. W programie UE miała także podjąć dodatkowe działania w celu stabilizacji sytuacji w Libii. Celem polityki Unii Europejskiej zarysowanej w programie ds. migracji było także zwiększenie zdolności ratowania życia na Morzu Śródziemnym przez kraje Afryki Północnej. Zgodnie z ideą wsparcia państw pochodzenia oraz integracji regionalnej Unia Europejska zadecydowała o przekazaniu środków w wysokości $24 \mathrm{mln}$ euro na regionalne programy mobilności pracowników we Wspólnocie Gospodarczej Państw Afryki Zachodniej. Takie działania mają na celu połączenie działań na rzecz zrównoważonego rozwoju oraz rozwiązania problemów migracyjnych (Komisja Europejska, 2015a, s. 10-13).

Istotnym działaniem podjętym w ramach europejskiego programu w zakresie migracji było przekształcenie byłej agencji Frontex, które ma służyć ustanowieniu zintegrowanego systemu zarządzania granicami. Inicjatorem tych zmian była Komisja Europejska, która 15 grudnia 2015 roku przedłożyła w tej sprawie wniosek ustawodawczy. Po zakończeniu procedury ustawodawczej Parlament Europejski i Rada Unii Europejskiej przyjęły rozporządzenie o ustanowieniu Europejskiej Straży Granicznej i Przybrzeżnej (ESGiP), która ma się składać z organów państw członkowskich odpo- 
wiedzialnych za zarządzanie granicami, w tym straży przybrzeżnych zakresie zadań kontroli granicznej oraz nowo powstałej Agencji Straży Granicznej i Przybrzeżnej (EASGiP). Agencja ta otrzymała znacznie większe kompetencje niż Frontex, ponieważ do jej zadań należy monitorowanie ruchów migracyjnych, zapobieganie kryzysom, zarządzanie granicami zewnętrznych i organizowanie powrotów dla nielegalnych imigrantów (Komisja Europejska, 2015a, s. 14). Mimo reformy zwyczajowo utrzymała się nazwa Frontex, która odnosi się także do nowo utworzonej agencji.

\section{Postanowienia szczytu w Valletcie}

Początkowo piąty szczyt Unia Europejska-Afryka był planowany na rok 2017 i miał się odbyć w Afryce, jednak pogarszająca się sytuacja na granicach zewnętrznych Unii Europejskiej doprowadziła do przyspieszenia jego organizacji (Kaczmarek, 2017, s. 35). W kwietniu 2015 r. Rada Europejska zaapelowała o organizację międzynarodowego szczytu z udziałem Unii Europejskiej oraz państw afrykańskich, który w obliczu nadzwyczajnej sytuacji na granicach zewnętrznych miałby zostać poświęcony wyłącznie migracji. W dniach 11-12 listopada, w stolicy Malty Valletcie spotkali się przedstawiciele krajów Unii Europejskiej oraz szefowie afrykańskich państw lub rządów. W wyniku jego ustaleń przyjęto plan działania i wspólną deklarację polityczną oraz ustanowiono nadzwyczajny fundusz powierniczy na rzecz Afryki.

Plan działania opierał się na pięciu kluczowych zagadnieniach, które dotyczyły korzyści rozwojowych związanych z migracją i eliminacji pierwotnych przyczyn natężonej migracji i czynników zmuszających ludzi do opuszczenia ich miejsc zamieszkania; zacieśnienia współpracy w zakresie legalnej migracji i mobilności; zwiększenia ochrony migrantów i osób ubiegających się o azyl; przeciwdziałanie nieuregulowanej migracji; rozwój współpracy w zakresie powrotów, readmisji i reintegracji. W obrębie tych zagadnień wyróżniono łącznie 16 inicjatyw o charakterze priorytetowym, które winne były zostać zrealizowane do końca 2016 r. Do implementacji planu działania miały zostać wykorzystane istniejące mechanizmy w ramach procesu rabackiego, procesu chartumskiego i wspólnej strategii UE-Afryka (Valleta Summit, s. 1-17). Najważniejsze postanowienia planu działania przywołano ponadto w wyżej wspomnianej deklaracji politycznej.

Do podstawowych zadań nowo utworzonego nadzwyczajnego funduszu powierniczego na rzecz Afryki należą kwestie stabilności w wybranych regionach kontynentu afrykańskiego, zwalczanie nielegalnej migracji i wyeliminowanie jej podstawowych przyczyn, a także poprawa zarządzania granicami. W trakcie funkcjonowania uruchomiono także projekty dotyczące tworzenia nowych miejsc pracy. Funkcjonowanie instrumentu określono wstępnie na lata 2015-2020, z możliwością przedłużenia w razie potrzeby. Fundusz miał być adresowany do trzech regionów: Afryki Północnej, Sahelu, Półwyspu Somalijskiego wraz obszarem wokół Jeziora Czad. Regiony te zostały wybrane ze względu na fakt, że to właśnie z nich pochodzi przeważająca część migrantów próbujących przedostać się do Unii Europejskiej. W założeniu miał on być finansowany z zasobów pochodzących z funduszy europejskich, głównie z Europejskiego Funduszu Rozwoju oraz z wpłat od państw członkowskich, a także pozostających poza UE: Norwegii i Szwajcarii. Na początku Komisja udostępniła środki w wysokości 1,8 mld euro 
oraz zachęciła państwa członkowskie do aktywnego wsparcia funduszu. Jak się później okazało, w 2016 r. wpłaty pochodzące z tego źródła finansowania osiągnęły niespełna $90 \mathrm{mln}$ euro. W zaistniałych okolicznościach Komisja Europejska była zmuszona do zwiększenia finansowania z funduszy europejskich (Castillejo, 2016, s. 1-9).

\section{Globalna strategia na rzecz polityki zagranicznej i bezpieczeństwa Unii Europejskiej}

Na posiedzeniu 28 czerwca 2016 r. Rada Europejska przyjęła globalną strategię na rzecz polityki zagranicznej i bezpieczeństwa Unii Europejskiej „Wspólna wizja, wspólne działania: Silniejsza Europa" (Wspólna, s. 1). Z powodu trwającego kryzysu migracyjnego poświęcono w niej sporo miejsca dla tematu migracji. W tym kontekście określono także ogólną strategię UE wobec Afryki. Istotnym elementem tej strategii ma być inwestowanie w poprawę odporności na kryzysy i destabilizację państw, społeczeństw i regionów położonych na południe od Europy. Ponadto UE zobowiązała się do wspierania wielostronnej współpracy w regionie Maghrebu. W strategii podkreślono także wykorzystanie Unii na rzecz Regionu Morza Śródziemnego m.in. do zapewnienia bezpieczeństwa granic i zwalczania terroryzmu1. W obliczu rosnącej współzależności między Afryką Północną a Subsaharyjską oraz Rogiem Afryki i Bliskim Wschodem UE ma wspierać współpracę w tych regionach, szczególnie w dziedzinie bezpieczeństwa. W przywołanej strategii Unia Europejska zobowiązała się także do ściślejszej współpracy z Unią Afrykańską, Wspólnotą Gospodarczą Państw Afryki Zachodniej (ECOWAS) i Grupą Pięciu na rzecz Sahelu odnośnie zmian transgranicznych w regionie północnej i Zachodniej Afryki, Sahelu, Jeziora Czad. UE traktuje działania na rzecz pokoju i rozwoju w Afryce jako inwestycję we własne bezpieczeństwo i dobrobyt (Wspólna, s. 31-33). Lepsza koordynacja polityk unijnych ma według strategii przyczynić się do poprawy bezpieczeństwa żywnościowego, zapobieganiu konfliktom, zwalczaniu terroryzmu i w zakresie migracji i zarządzania granicami. Strategia Unii Europejskiej ma być realizowana przede wszystkim przy użyciu dyplomacji prewencyjnej i mediacji, instrumentów funkcjonujących w zakresie wspólnej polityki bezpieczeństwa i obrony oraz funduszy powierniczych. Unia Europejska postawiła sobie za cel wspieranie krajów tranzytu w zwiększeniu ich zdolności przyjmowania i udzielania azylu, także powstrzymanie nieregularnych przepływów migracyjnych poprzez poprawę efektywności powrotów (Wspólna, s. 46-49).

\section{Współpraca na poziomie regionalnym}

Proces z Rabatu zapoczątkowany został na konferencji w 2006 r. W proces zaangażowanych jest łącznie 55 państw, w tym europejskich i afrykańskich należących do

${ }^{1}$ Do Unii na rzecz Regionu Morza Śródziemnego należy pięć państw afrykańskich: Algieria, Egipt, Mauretania, Maroko, Tunezja, Libia ma status obserwatora. Warto jednak zaznaczyć, że członkiem wspólnoty jest również Liga Państw Arabskich, co pośrednio zwiększa udział państw afrykańskich w tej inicjatywie UE. 
ECOWAS. Proces łączy we współpracy państwa położone wzdłuż szlaku migracyjnego przebiegającego przez Centralną, Zachodnią i Północną Afryką do Europy. Nadrzędnym celem inicjatywy jest pogłębienie współpracy w zakresie migracji. Proces jest zarządzany przez komitet sterujący, w którego skład wchodzi Komisja Europejska, ECOWAS oraz po pięć państw członkowskich Unii Europejskiej oraz pięć krajów partnerskich $^{2}$ (Komisja Europejska, 2015b, s. 2-3).

Pod egidą procesu z Rabatu powstała sieć trwałych wielostronnych i subregionalnych inicjatyw. Jako przykład takiej współpracy często wymieniana jest sieć Seahorse, której przedmiotem działalności jest walka z nielegalną migracją i przemytem ludzi na obszarze Atlantyku. W ramach sieci współpracują: Hiszpania, Portugalia, Senegal, Mauretania, Republika Zielonego Przylądka, Maroko, Gambia i Gwinea Bissau (Komisja Europejska, 2015b, s. 3).

W ramach procesu z Rabatu organizowane są konferencje na szczeblu ministerialnym. W reakcji na wzmożoną migrację do Europy 28 listopada 2014 r. na czwartej euro-afrykańskiej konferencji w sprawie migracji i rozwoju przyjęto deklarację rzymską i program na lata 2015-2017, w którym założono dwa priorytetowe obszary tematyczne: wzmocnienie związku między migracją i rozwojem oraz zapobieganie nielegalnej migracji. W programie zwrócono także uwagę na ochronę międzynarodową, dostosowując tym działania w ramach procesu rabackiego do wytycznych zawartych w wyżej wspomnianym GPMM (Declaration, s. 1).

Na kolejnej konferencji ministerialnej, która odbyła się 2 maja 2018 r. w Marrakeszu, przyjęto program na lata 2018-2020. Brał on pod uwagę podejście regionalne przy jednoczesnym poszanowaniu suwerenności państw. Program w zasadzie powtarzał postanowienia wspomnianego wyżej planu działania przyjętego podczas szczytu UE-Afryka w Valletcie. Celem takiego podejścia była spójność działań i połączenie środków, która ma przyczynić się do lepszej efektywności wdrożenia założeń programu. Państwa podkreśliły, że implementacja planu musi być realizowana przy pełnym poszanowaniu dla praw człowieka (Fifth, s. 1).

Proces chartumski został zapoczątkowany podczas konferencji ministerialnej w Rzymie 28 listopada 2014 r. Jego struktura oraz sposób zarządzania są zbliżone do procesu z Rabatu. Według deklaracji rzymskiej współpraca w ramach procesu ma mieć charakter bilateralny i regionalny, a jej głównym celem jest walka z nielegalną migracją u źródeł. W kooperację zaangażowane są państwa pochodzenia, tranzytu i docelowe ${ }^{3}$. Proces zakłada, że współpraca winna opierać się na dobrowolnej wymianie informacji, szczególnie w następujących dziedzinach: szkoleń, poprawy efektywności służb, wsparcia technicznego i wymianie najlepszych praktyk. Zaangażowane państwa mogą dobrowolnie poprosić o wsparcie dla służb zajmujących się zarządzaniem migracją na poziomie operacyjnym. Mogą one również otrzymać pomoc przy organizacji kam-

${ }^{2}$ Są to Belgia, Włochy, Portugalia, Hiszpania, Burkina Faso, Gwinea Równikowa, Mali, Maroko i Senegal.

${ }^{3}$ Deklarację rzymską podpisały następujące strony: 28 państw członkowskich UE, Dżibuti, Egipt, Erytrea, Etiopia, Kenia, Litwa, Somalia, Sudan Południowy, Sudan, Tunezja, Wysoki Przedstawiciel Unii, Wice-Przewodniczący Komisji Europejskiej, Komisarze do spraw migracji i rozwoju Unii Afrykańskiej. Po utworzeniu stabilnego rządu do procesu dołączyła także Libia, w inicjatywę zaangażowały się także Norwegia, Szwajcaria i Uganda. 
panii informujących o zagrożeniach związanych z nielegalną migracją, przemytem i handlem ludźmi. Aby wzmocnić koordynację działań horyzontalnych, poszczególne państwa powinny wprowadzić narodowe strategie zwalczające nielegalną migrację (Komisja Europejska, 2015b, s. 2).

Za pomocą tych strategii państwa partnerskie powinny poprawić efektywność służb porządkowych, systemu sądownictwa i walki z korupcją, tak aby skuteczniej walczyć z sieciami przemytniczymi, które często wykorzystują słabości sektora publicznego. $\mathrm{Z}$ tego powodu deklaracja rzymska mówi o konieczności pełnej implementacji oraz ratyfikacji aktów prawa międzynarodowego, takich jak: konwencja Narodów Zjednoczonych w sprawie międzynarodowej przestępczości zorganizowanej (Konwencja) oraz protokół przeciwko przemytowi migrantów drogą lądową, morską i powietrzną (Protokót). Oba akty zostały przyjęte przez Zgromadzenie Ogólne ONZ w 2000 r. Dodatkowo państwa uczestniczące w procesie chartumskim winny promować zrównoważony rozwój, który sprzyja eliminacji przyczyn nielegalnej migracji. Wartością dodaną dla procesu byłoby zaangażowanie społeczeństwa obywatelskiego $\mathrm{w}$ walkę z nieuregulowaną migracją, a także dobrowolne otwarcie centrów pomocy dla migrantów przy poszanowaniu dla praw człowieka (Declaration, s. 1-5).

Za zarządzanie procesem chartumskim odpowiedzialny jest komitet sterujący, w którego skład wchodzi pięć państw członkowskich UE oraz pięć krajów partnerskich $^{4}$, Komisja Europejska, Europejska Służba Działań Zewnętrznych i Komisja Unii Afrykańskiej. Drugim organem sterującym procesem jest prezydencja, która zwołuje i przewodniczy kolejnym spotkaniom. Jako pierwszy prezydencję pełnił Egipt, następnie w 2017 r. został zastąpiony przez Etiopię, od której funkcję przejęły Włochy. Sprawami administracyjnymi zajmuje się sekretariat, którym wspólnie zarządzają Komisja Unii Afrykańskiej i Komisja Europejska (Actors and governance, s. 1).

\section{Współpraca bilateralna}

Jeszcze w 2011 r. Komisja Europejska za podstawę współpracy bilateralnej w dziedzinie migracji uznawała partnerstwo na rzecz mobilności (Komisja Europejska, 2011, s. 8-11). Pierwszym partnerstwem na rzecz mobilności w Afryce była umowa zawarta w 2008 r. z Republiką Zielonego Przylądka (Council of the European Union, 2008, s. 1). W 2013 r. UE zawarła partnerstwo na rzecz mobilności z Marokiem. W 2014 r. podpisano umowę partnerstwa $\mathrm{z}$ Tunezją. Instrument ten nie zyskał jednak oczekiwanej popularności w przypadku współpracy z państwami afrykańskimi.

W komunikacie z dnia 7 czerwca 2016 r. Komisja Europejska zaproponowała ustanowienie nowych ram partnerstwa z państwami trzecimi w ramach Europejskiego programu w zakresie migracji (Komisja Europejska, 2016, s. 1). Unia Europejska poprzez partnerstwo z krajami trzecimi powinna wykorzystać wszystkie dostępne instrumenty polityki rozwojowej, sąsiedztwa, azylu i ochrony granic zewnętrznych. Kompleksowe partnerstwa winny być zawierane $\mathrm{w}$ formie porozumień $\mathrm{z}$ państwami pochodzenia lub

${ }^{4}$ Są to: Włochy, Francja, Niemcy, Wielka Brytania, Malta, Egipt, Erytrea, Etiopia, Sudan Południowy i Sudan. 
tranzytu migrantów. Kluczowym elementem tych porozumień miała być skuteczna polityka w zakresie powrotów, readmisji i reintegracji wobec osób, którym nie może zostać przyznana ochrona międzynarodowa. Poprzez zawieranie takich umów UE chce otrzymać wymierny wzrost liczby powrotów i readmisji. Komisja wyróżniła 16 krajów priorytetowych, z których aż 13 stanowily państwa afrykańskie ${ }^{5}$. W państwach priorytetowych zaplanowano rozmieszczenie europejskich oficerów łącznikowych ds. migracji, którzy ułatwialiby koordynację należytych działań.

W dniach 29-30 listopada 2017 r., w Abidżanie odbył się piąty szczyt Unia Afrykańska-Unia Europejska, istotny dla współpracy z Libią. Szefowie państw lub rządów i przywódcy Unii Europejskiej przyjęli wspólną deklarację polityczną, w której poparli dotychczasowe działania na rzecz zwalczania nielegalnej migracji oraz zaliczyli migrację i mobilność do strategicznych priorytetów do czasu zwołania następnego szczytu. W rezultacie utworzono wspólną grupę zadaniową, w skład której wchodzili przedstawiciele Unii Afrykańskiej, Unii Europejskiej i Organizacji Narodów Zjednoczonych. Grupa ta, we współpracy z Międzynarodową Organizacją do spraw Migracji (IOM), udzieliła wsparcia dla 15 tys. migrantów w Libii w powrocie do ich krajów pochodzenia, a także aktywnie zwalczała siatki przemytnicze i handel ludźmi. W dalszych działaniach grupa winna kontynuować dotychczasową misję oraz podjąć współpracę $\mathrm{z}$ administracją libijską $\mathrm{w}$ celu zaprzestania długotrwałego przetrzymywania migrantów w obozach (Investing, s. 1-13).

\section{Uwagi końcowe}

Podsumowując niniejsze rozważania, należy zwrócić uwagę na fakt, że rosnąca liczba migrantów napływających do Europy, która latem 2015 r. wkroczyła w fazę kryzysową, stanowiła wyraźny asumpt do zmian w polityce Unii Europejskiej wobec Afryki na wszystkich poziomach współpracy. Zmiany te były inicjowane w głównej mierze odgórnie przez Komisję Europejską, zgodnie z podejściem top down. Dotyczyły one wszystkich poziomów współpracy od ogólnej strategii wobec kontynentu afrykańskiego, poprzez grupy państw skupionych wokół regionów, aż po współpracę bilateralną z wybranymi państwami o kluczowym znaczeniu. Działania podjęte przez Unię Europejską miały za zadanie przede wszystkim powstrzymać falę nieuregulowanej migracji do UE. Dlatego na pierwszy plan wysunięto inicjatywy związane $\mathrm{z}$ lepszym zarządzaniem granicami i walką z sieciami przemytniczymi.

Dopiero w dłuższej perspektywie nacisk kładziono na politykę rozwojową i wyeliminowanie przyczyn nielegalnej migracji w państwach pochodzenia. Należy jednak podkreślić, że mimo przesłanek podejścia realistycznego UE jako globalny aktor na arenie stosunków międzynarodowych wciąż przekonuje o swoim podejściu liberalnym, podkreślając wagę praw człowieka i ochrony jednostki. Znajduje to odzwierciedlenie w analizowanych dokumentach, w których Unia Europejska stara się pogodzić te dwa sprzeczne podejścia. Jednak utrzymywanie wysokich wydatków na politykę

${ }^{5}$ Za priorytetowe państwa z Afryki uznano: Etiopię, Erytreę, Mali, Nigerię, Senegal, Somalię, Sudan, Ghanę, Wybrzeże Kości Słoniowej, Algierię, Maroko, Tunezję. 
rozwojową wzmacnia softpower Unii Europejskiej, która traktowana jest jako uczciwy i rzetelny partner w relacjach międzynarodowych. Wielość zapętlających się inicjatyw w postaci planów działania programów regionalnych, strategii, deklaracji, funduszy i projektów ma dać efekt w postaci synergii. Z drugiej strony, utrudnia to zarządzanie i koordynację działań, co często jest problemem w przypadku zastosowania zarządzania wielopoziomowego.

\section{Bibliografia}

Actors and governance (2016), The Khartoum Process, https://www.khartoumprocess.net/about/ actors-and-governance.

Barcz J., Kawecka-Wyrzkowska E., Michałowska-Gorywoda K. (2012), Integracja europejska $w$ świetle Traktatu z Lizbony Aspekty ekonomiczne, Polskie Wydawnictwo Ekonomiczne, Warszawa.

Bisong A. (2018), Trans-regional institutional cooperation as multilevel governance: ECOWAS migration policy and the EU, „Journal of Ethnic and Migration Studies”, vol. 44.

Castillejo C. (2016), The European Union Trust Fund for Africa: A Glimpse of the Future for EU Development Cooperation, „Discussion Paper”, $\mathrm{nr} 22$.

Council of the European Union (2008), Joint Declaration on Mobility Partnership between the European Union and the Republic of Cape Verde, https://ec.europa.eu/home-affairs/sites/ homeaffairs/files/what-we-do/policies/international-affairs/global-approach-to-migration/ specific-tools/docs/mobility_partnership_cape_verde_en.pdf.

Council of the European Union (2018), Outcome of the Council Meeting, 3626th Council meeting, Economic and Financial Affairs, Brussels 22 June 2018, Economic and Financial Affairs, http://www.consilium.europa.eu/media/35761/st10203-en18.pdf.

Declaration of the Ministerial Conference of the Khartoum Process (EU-Horn of Africa Migration Route Initiative) Rome, 28th November 2014, https://www.khartoumprocess.net/resources/ library/download/file?fid=20.60.

Dyrektywa Parlamentu Europejskiego i Rady 2011/36/UE z dnia 5 kwietnia 2011 r., w sprawie zapobiegania handlowi ludźmi i zwalczania tego procederu oraz ochrony ofiar zastępująca decyzję ramowa Rady 2002/629/WSiW, Dziennik Urzędowy Unii Europejskiej L 101/1.

Eurostat (2018), Asylum and first time asylum applicants by citizenship, age and sex Annual aggregated data (rounded), http://ec.europa.eu/eurostat/data/database.

Frankowski P. (2011), Umowy o partnerstwie gospodarczym jako instrument promowania integracji regionalnej w Afryce Subsaharyjskiej, Centrum Europejskie Natolin, Warszawa.

Fitth Ministerial Conference of the Euro-African Dialogue on Migration and Development (2018), Rabat Process Euro-African Dialogue on Migration and Development, https://www.rabatprocess.org/en/in-action/dialogue/321-fifth-ministerial-conference-of-the-euro-african-dialogue-on-migration-and-development.

Investing in Youth for Accelerated Inclusive Growth and Sustainable Development (2017), African Union-European Union Summit 2017, http://www.consilium.europa.eu/media/31991/33454pr-final_declaration_au_eu_summit.pdf.

Kaczmarek F. (2017), Stanowisko Parlamentu Europejskiego wobec migracji w kontekście polityki spójności na rzecz rozwoju, w: Między tolerancja a niechęcią. Polityka wspótczesnych państw europejskich wobec migrantów i mniejszości, red. A. Adamczyk, A. Sakson, C. Trosiak, Wydawnictwo Naukowe Wydziału Nauk Politycznych i Dziennikarstwa Uniwersytetu im. Adama Mickiewicza w Poznaniu, Poznań. 
Konwencja Narodów Zjednoczonych przeciwko międzynarodowej przestępczości zorganizowanej, Dz. U. 2005, Nr 18, poz. 158.

Komisja Europejska (2011), Komunikat Komisji do Parlamentu Europejskiego, Rady, Europejskiego Komitetu Ekonomiczno-Społecznego i Komitetu Regionów Globalne podejście do kwestii migracji i mobilności, KOM (2011) 743 wersja ostateczna.

Komisja Europejska (2015a), Komunikat Komisji do Parlamentu Europejskiego, Rady, Europejskiego Komitetu Ekonomiczno-Społecznego i Komitetu Regionów Europejski Program w Zakresie Migracji, KOM (2015) 240 wersja ostateczna.

Komisja Europejska (2015b), Wspótpraca Unii Europejskiej z Afryka w zakresie migracji, Bruksela, 9 listopada 2015, http://europa.eu/rapid/press-release_MEMO-15-6026_pl.pdf.

Komisja Europejska (2016), Komunikat Komisji do Parlamentu Europejskiego, Rady Europejskiej, Rady i Europejskiego Banku Inwestycyjnego w sprawie ustanowienia nowych ram partnerstwa z państwami trzecimi w ramach Europejskiego programu w zakresie migracji.

Morawska K. A. (2017), Partnerstwo na rzecz mobilności jako instrument polityki imigracyjnej Unii Europejskiej, „Ruch Prawniczy, Ekonomiczny i Socjologiczny, z. 2.

Nitszke A. (2016), W kierunku nowej Europejskiej Polityki Sąsiedztwa, „Rocznik Integracji Europejskiej", nr 10.

Protokót przeciwko przemytowi migrantów droga lądowa, morska i powietrzna, uzupetniający Konwencje Narodów Zjednoczonych przeciwko międzynarodowej przestępczości zorganizowanej, przyjęty przez Zgromadzenie Ogólne Narodów Zjednoczonych dnia 15 listopada 2000 r., Dz. U. 2005, Nr 18, poz. 162, http://prawo.sejm.gov.pl/isap.nsf/download.xsp/ WDU20050180162/O/D20050162.pdf.

Rada Europejska (2005), Wnioski Prezydencji, 15-16 grudnia 2005 r., Szczyt Rady Europejskiej w Hampton Court.

Traktat o funkcjonowaniu Unii Europejskiej (wersja skonsolidowana), Dziennik Urzędowy Unii Europejskiej C, 2012, nr 326.

Traktat o Unii Europejskiej (wersja skonsolidowana), Dziennik Urzędowy Unii Europejskiej C, 2012, nr 326.

Umowa o partnerstwie między członkami grupy państw Afryki, Karaibów i Pacyfiku z jednej strony a Wspólnota Europejska i jej Państwami Członkowskimi z drugiej strony, podpisana w Kotonu 23 czerwca 2000 roku (2000).

Valetta Summit, 11-12 November 2015, Action Plan, http://www.consilium.europa.eu/media/21839/ action_plan_en.pdf.

Węc J. J. (2017), Reforma polityki imigracyjnej, kontroli granic zewnętrznych oraz polityki azylowej Unii Europejskiej w dobie kryzysu migracyjnego (2015-2016), „Przegląd Zachodni”, nr 2.

Wojna B. (2011), Unia Europejska wobec poludniowych sasiadów: nowe wyzwania dla europejskiej polityki sasiedztwa.

Wspólna wizja, wspólne działanie: Silniejsza Europa Globalna strategia na rzecz polityki zagranicznej i bezpieczeństwa Unii Europejskiej (2016), https://europa.eu/globalstrategy/sites/globalstrategy/files/eugs_pl_version.pdf.

\section{Streszczenie}

Celem artykułu jest przegląd polityki Unii Europejskiej wobec Afryki w kontekście kryzysu migracyjnego w latach 2011-2017. Analiza źródeł w postaci aktów prawnych i dokumentów Unii Europejskiej pozwoliła na identyfikację zmian w wymiarze zewnętrznym różnych polityk unijnych adresowanych do państw afrykańskich. W niniejszej pracy skupiono są na przedstawieniu ram polityki Unii Europejskiej wobec Afryki. Następnie przybliżono zjawisko 
intensyfikacji migracji z tego kontynentu do Europy. Zaprezentowano także odpowiedź Unii Europejskiej na problem wzmożonej presji na granice zewnętrzne.

Słowa kluczowe: Unia Europejska, kryzys migracyjny w Unii Europejskiej, działania zewnętrzne Unii Europejskiej, Europejska Polityka Sąsiedztwa, Europejska Służba Działań Zewnętrznych

\section{Aspects of the policy of the European Union towards Africa in the context of migration crisis}

\section{Summary}

The aim of the article is to explore the policy of the European Union towards Africa between 2011-2017 in the context of migration crisis. Analysis of the legal acts and soft law documents of the European Union allowed to recognize the changes in the external dimension of the different EU policies addressed to African countries. In the article author focused on the framework of the European Union policy towards Africa and the phenomenon of the intensified migration from this continent into Europe. Then, the reaction of the European Union to the high migration pressure on its external borders has been explored.

Key words: European Union, migration crisis in the European Union, external actions of the European Union, European Neighbourhood Policy, European External Action Service 
